\title{
MORAL PAJAK: SEBUAH OPSI PENINGKATAN KEPATUHAN PAJAK MASYARAKAT MUSLIM
}

\author{
Imanda Firmantyas Putri Pertiwi \\ IAIN Surakarta \\ Email: imanda.fp@iain-surakarta.ac.id
}

\begin{abstract}
This study aims to determine the significance of taxpayer internal factors to comply with applicable tax laws. Variable religiosity and nationalism become exogenous variables to define tax morale, while tax morale will define tax compliance. Samples taken over 200 individual taxpayers whose Islam religion. Data analysis was done using Structural Equation Model (SEM) by dividing the step into outer test and inner test. The results showed that statistically religiosity influence tax morale, but on the contrary, nationalism is not shown significant results. Tax morale on tax compliance showed positive results and significant. Based on these results, can be concluded that religiosity still plays an important role in moslem society's decision making. Thus, if the tax policy makers can touch the side ofreligiosity of the moslem societies, that in fact as majority in this country, it is expected that tax revenues can be increased.
\end{abstract}

Keywords: religiosity, tax morale, national pride, tax compliance

\section{PENDAHULUAN}

Secara historis, wajib pajak diasumsikan selalu melakukan penghindaran pajak sehingga dibutuhkan pengetahuan mengenai faktor-faktor apa saja yang setidaknya dapat mengurangi sikap negatif para wajib pajak tersebut (Benk et.al., 2016). Menurut James and Alley (2004), terdapat dua pendekatan yang dapat digunakan untuk menganalisa faktor-faktor yang mempengaruhi kepatuhan pajak, yaitu pendekatan ekonomi dan perekonomi dan pendekatan perilaku.

Penelitian yang menggunakan pendekatan ekonomi pada umumnya mengangkat variabel pemeriksaan pajak dan denda pajak. ${ }^{1}$ Melalui pendekatan ekonomi ada juga peneliti yang mengangkat dari sisi pendapatan wajib pajak, ${ }^{2}$ sisi tarif pajak (Takats, 2008), dan sisi audit pajak. ${ }^{3}$ Sedangkan pada pendekatan perilaku, aspek terpenting yang diangkat adalah aspek psikis yang dimiliki oleh wajib pajak, yang merupakan manusia-manusia yang secara fitrahnya menurut Anwar memiliki fitrah jasmani (aspek biologis), fitrah ruhani (aspek psikis) maupun fitrah nafs (aspek psiko fisik).

Beberapa penelitian yang mengangkat dari pendekatan perilaku adalah Togler yang mengangkat isu religiusitas, ${ }^{4}$ Razak dengan variabel sikapnya, ${ }^{5}$ dan Cyan dengan tema moral pajak. ${ }^{6}$ Ada pula penelitian yang mengangkat isu patriotisme atau nasionalisme, namun belum ada penelitian yang secara bersama-sama mengangkat religiusitas dan nasionalisme secara bersama-sama dalam mempengaruhi kepatuhan pajak. Hal ini barangkali dipengaruhi oleh

\footnotetext{
1 Cahyonowati, N., Model Moral Dan Kepatuhan Perpajakan : JAAI, Vol. 15 No, 2011, 161-177.

2 Bloomquist, K. M., Tax Evasion, Income Inequality And Opportunity Costs Of Compliance Office Of Research Paper Presented At The 96 Th Annual Conference. In Paper Presented At The 96th Annual Conference Of The National Tax Association, h.

3 Modugu, K. P, Impact Of Tax Audit On Tax Compliance In Nigeria, 5(9), 2014, h. 207-215.

4 Torgler, B., The Importance Of Faith : Tax Morale And Religiosity. Journal Of Economic Behavior \&Organization, 61, 2006 , h. 81-109.

5 Razak, A. A., \&Adafula, C. J, Evaluating Taxpayers ' Attitude And Its Influ Ence On Tax Compliance Decisions In Tamale, Ghana, 5(September), 2013, h. 48-57.

6 Cyan, M. R., Koumpias, A. M., \&Martinez-Vazquez, J., The Determinants Of Tax Morale In Pakistan. Journal Of Asian Economics, 47, 2016, h. 23-34.
} 
karakter suatu bangsa, dimana dengan karakter bangsa yang sekuler, maka hal yang berkaitan dengan agama dan kenegaraan akan dipisahkan jauh-jauh. ${ }^{7}$

Penelitian ini ingin menonjolkan karakter bangsa Indonesia sebagai bangsa yang menempatkan agama sebagai bagian yang tak terpisahkan dari negara, bahkan dijadikan unsur utama (walaupun bukan satu-satunya), terbukti dengan apa yang ada pada sila pertama Pancasila. Penelitian ini hendak mengakomodasi aspek psikis yang berkaitan dengan "rasa". Rasa cinta kepada agama (religiusitas) maupun kepada bangsa dan negara (nasionalisme). Religiusitas merupakan nilai-nilai atau prinsip yang dianut oleh seseorang yang didasari oleh agama yang dianutnya. ${ }^{8}$ Sedangkan nasionalisme adalah suatu paham, yang berpendapat bahwa kesetiaan tertinggi individu harus diserahkan kepada negara kebangsaan.

Luaran yang diharapkan dapat dihasilkan oleh penelitian ini adalah rekomendasi bagi para pemangku kebijakan yang berkaitan dengan pajak mengenai pentingnya mempertimbangkan faktor moral pajak yang dibentuk oleh variabel religiusitas dan nasionalisme. Hal ini menjadi suatu urgensi mengingat suatu fakta bahwa tax ratio Indonesia masih pada tingkat yang sangat rendah dan belum memenuhi target. Bahkan, di tahun 2015, tax ratio mengalami penurunan dari angka 11,9\% di tahun 2014 menjadi 10,88 di tahun 2015. Bila dibandingkan dengan negara tetangga, Indonesia juga tertinggal cukup jauh, Filipina tax ratio-nya mencapai $12 \%$, Malaysia memiliki tax ratio $16 \%$ dan Singapura $22 \% .9$

“Ungkap, tebus, lega”, tagline ini dibuat oleh Direktorat Jendral Pajak Kementerian Keuangan dalam rangka sosialisasi program tax amnesty yang pada rencananya akan diselenggarakan dari bulan Oktober 2015 hingga Maret 2017. Amnesti pajak adalah program pengampunan yang diberikan oleh pemerintah kepada Wajib Pajak meliputi penghapusan pajak yang seharusnya terutang, penghapusan sanksi administrasi perpajakan, serta penghapusan sanksi pidana di bidang perpajakan atas harta yang diperoleh pada tahun 2015 dan sebelumnya yang belum dilaporkan dalam SPT, dengan cara melunasi seluruh tunggakan pajak yang dimiliki dan membayar uang tebusan. ${ }^{10}$

Program tax amnestyini merupakan bukti bahwa masih banyaknya ketidakpatuhan perpajakan (tax avoidance) dari para wajib pajak sehingga pemerintah merasa perlu untuk lebih baik memberikan pengampunan dan kelonggaran pembayaran untuk kemudian mendapatkan pemasukan berupa uang tebusan dibanding menunggu kesadaran wajib pajak yang memiliki pajak terutang untuk membayarkan pajak terutangnya.

\section{Kajian Teoretis}

\section{Religiusitas, Moral Pajak dan Kepatuhan Pajak}

Kajian yang mengkaitkan antara religiusitas dan moral pajak dilakukan oleh Togler. Penelitiannya yang dilakukan dengan mengambil data dari 32 negara menyatakan bahwa faktor religiusitas secara signifikan meningkatkan moral pajak. Pertanyaan umum yang diajukan Togler sebagai indikator untuk menjelaskan variabel religiusitas adalah mengenai seberapa seringnya datang ke gereja, bagaimana pendidikan agamanya, apakah aktif atau tidak di suatu organisasi keagamaan, religiusitas yang dirasakan, seberapa dalam memahami tuntunan agamanya, seberapa besar kepercayaannya kepada gereja, dan untuk mengontrolnya maka agama spesifik yang dipilih dalam penelitian ini.

\footnotetext{
${ }^{7}$ Lavoie, R., Digital Commons At Loyola Marymount Patriotism And Taxation: The Tax Compliance Implications Of The Tea Party Movement, 2011, h. 45.

${ }^{8}$ asri, Y. M. (N.D.). Pengaruh Gender , Religiusitas Dan Sikap Love Of Money Pada Persepsi Etika Penggelapan Pajak, 2015, h. 45-54. ${ }^{9}$ http:// www.kemenkeu.go.id/ Berita/ dirjen-pajak-tax-ratio-indonesia-masihrendah, diakses 17 November 2016.

10http:// www.pajak.go.id, diakses 12 November 2016.
} 
Variabel moral pajak diukur oleh Togler dengan menggunakan apakah individu tersebut pernah melalukan (1) kebohongan, yaitu dengan mengklaim tunjangan yang diberikan pemerintah, padahal ia tak berhak untuk menerimanya; (2) kecurangan, yaitu dengan tidak membayar tarif di angkutan umum; (3) membeli barang curian sementara orang tersebut tau bahwa barang tersebut merupakan hasil curian. ${ }^{11}$

Beberapa penelitian yang menghubungkan antara religiusitas dan kepatuhan pajak telah dilakukan, dimana salah satunya adalah penelitian oleh Mohdali yang meneliti tentang pengaruh religiusitas masyarakat Muslim di Turki terhadap kepatuhan pajak. Mohdali menemukan bahwa terdapat pengaruh yang signifikan untuk religiusitas intrapersonal dan tidak untuk religiusitas interpersonal. Mohdali membedakan variabel religiusitas ke dalam dua tipe. Yang pertama adalah religiusitas interpersonal dan religiusitas intrapersonal. Yang dimaksud dengan religiusitas interpersonal berkaitan dengan keyakinan dan sikap individu, dan komitmen agama interpersonal yang berasal dari keterlibatan individu dengan komunitas atau organisasi keagamaan. Penelitian sejenis dilakukan oleh Utama dan Wahyudi yang sebaliknya menemukan bahwa religiusitas interpersonal berpengaruh signifikan pada kepatuhan pajak dan religiusitas intrapersonal tidak.

Dalam teori etika, moral diistilahkan sebagai nilai-nilai atau prinsip-prinsip individu untuk membuat keputusan yang benar atau salah. Berangkat dari logika ini, tentunya keputusan untuk taat pajak ataupun tidak juga dipengaruhi oleh suatu nilai atau prinsip yang dianut oleh individu yang bersangkutan. Nilai atau prinsip tersebut apabila dikaitkan dengan agama dapat disebut dengan religiusitas. Religiusitas menurut Johnson dipandang sebagai sejauh mana individu berkomitmen terhadap agamanya serta keimanan dan menerapkan ajarannya sehingga sikap dan perilaku individu mencerminkan komitmen ini.12

Moral pajak dapat diartikan lebih luas dari religiusitas, dimana menurut Yucedogru sesuai dengan Gambar 1 terlihat bahwa religiusitas adalah bagian dari moral pajak yang dapat meningkatkan moral pajak. Moral pajak disepakati sebagai motivasi internal diri untuk membayar pajak. ${ }^{13}$

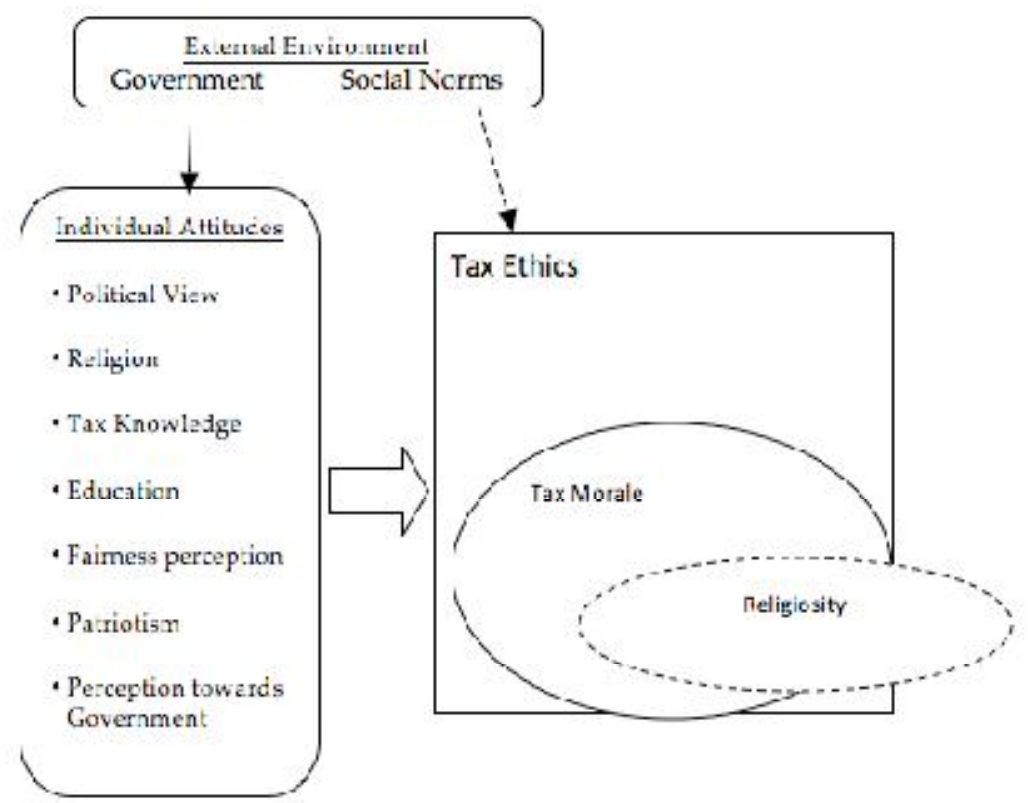

Gambar 1. Yucedogru's Figure

11Torgler, B, The Importance Of Faith : Tax Morale And Religiosity. Journal Of Economic Behavior \&Organization, 61, 2006, h.81-109.

12Utama,A. Pengaruh Religiusitas Terhadap Perilaku Kepatuhan Wajib Pajak Orang Pribadi Di Provinsi DKI Jakarta, (2), 2016, h.1-13.

13Torgler, B., The Importance Of Faith : Tax Morale And Religiosity. Journal Of Economic Behavior \&Organization, 61, 2006, h. 81-109. 
Model yang lebih lengkap untuk menjelaskan moral pajak dirumuskan oleh Cahyonowati. Model yang ia buat lebih komprehensif, moral pajak dipengaruhi oleh tiga variabel, dimana masing-masing variabel tersebut mempunyai beragam indikator. Berikut adalah model yang dikembangkan oleh Cahyonowati.14

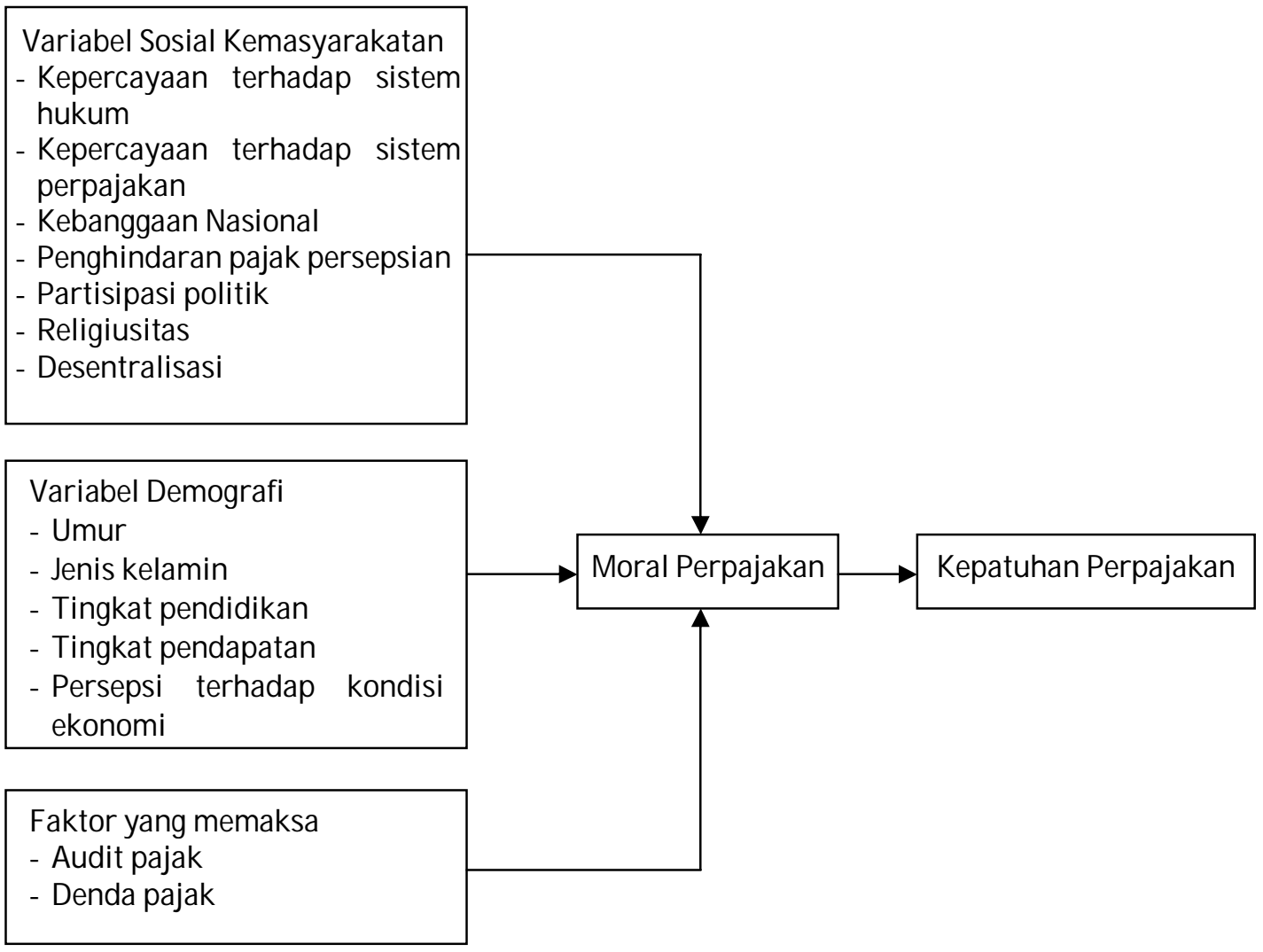

\section{Gambar 2. Model Teoretis Faktor-faktor yang Mempengaruhi Kepatuhan Perpajakan (Cahyonowati, 2011)}

Hasil dari penelitian Cahyonowati (2011) menyatakan bahwa dari sekian banyak variabel dan indikator yang mempengaruhi moral perpajakan, rupanya hanya denda pajak yang secara signifikan mempengaruhi moral perpajakan. Namun moral perpajakan sebagai motivasi intrinsik individu mempunyai determinan positif terhadap kepatuhan perpajakan.

Ada sebuah klaim bahwa penelitian pada komunitas non-muslim dengan komunitas muslim akan terdapat beberapa perbedaan (Yucedogru, 2013), oleh karenanya penelitian ini akan dibatasi mengukur religiusitas dalam scope komunitas muslim. Religiusitas dalam Islam menurut Ancok dan Suroso (2008) mencakup lima hal, yaitu (1) akidah, menyangkut keyakinan beragama, inti dimensi akidah dalam Islam adalah tauhid; (2) ibadah, menyangkut pelaksanaan hubungan antar manusia dengan Allah, berkaitan dengan ritual-ritual keagamaan; (3) amal (akhlak), menyangkut pelaksanaan hubungan manusia dengan sesama makhluk, saling tolong menolong, mennghormati, toleransi, dan lain sebagainya; (4) pengetahuan, menyangkut seberapa banyak seseorang memahami ajaran Islam, hukum-hukum Islam, sejarah Islam, dan lain sebagainya; dan (5) penghayatan, menyangkut perasaan kedekatan dengan Allah dan kenyamanan dalam beragama.

${ }^{14}$ Cahyonowati, N., Model Moral Dan Kepatuhan Perpajakan : JAAI, Vol. 15 No, 2011, h. 161-177 


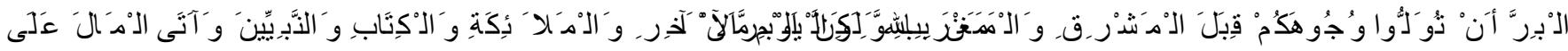

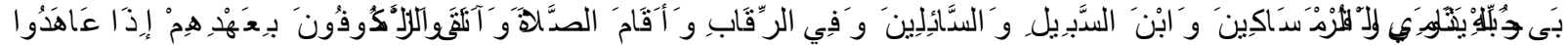

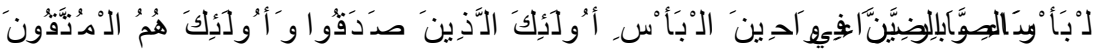

"Bukanlah menghadapkan wajahmu ke arah timur dan barat itu suatu kebajikan, akan tetapi sesungguhnya kebajikan itu ialah beriman kepada Allah, hari kemudian, malaikat-malaikat, kitab-kitab, nabi-nabi dan memberikan harta yang dicintainya kepada kerabatnya, anak-anak yatim, orang-orang miskin, musafir (yang memerlukan pertolongan) dan orang-orang yang meminta-minta; dan (memerdekakan) hamba sahaya, mendirikan shalat, dan menunaikan zakat; dan orang-orang yang menepati janjinya apabila ia berjanji, dan orang-orang yang sabar dalam kesempitan, penderitaan dan dalam peperangan. Mereka itulah orang-orang yang benar (imannya); dan mereka itulah orang-orang yang bertakwa (Al Baqarah: 177).

\section{Nasionalisme, Moral Pajak dan Kepatuhan Pajak}

Menghubungkan nasionalisme dengan kepatuhan dalam perpajakan telah dilakukan oleh beberapa literatur. Penelitian Lavoui menghubungkan patriotisme dengan kepatuhan pajak dalam hubungannya dengan gerakan "Tea Party Movement". Tea party movement adalah gerakan sebagian warga Amerika dalam rangka memprotes pemerintah dan kebijakan pajaknya. Dalam kesimpulannya Lavoui mengatakan bahwa berkaitan dengan tea party movement, patriotisme justru menjadi faktor penghalang bagi kepatuhan pajak. ${ }^{15}$

Berbeda dengan Lavoui, Konrad and Qari menemukan hubungan sangat kuat antara patriotisme dengan kepatuhan pajak, bahkan setelah dilakukan robustness test berkali-kali. Penelitian Konrad and Qari ini didukung oleh Purnamasari et.al. yang menyatakan bahwa nasionalisme berpengaruh positif signifikan terhadap kepatuhan membayar pajak. Masih menurut Purnamasari, wajib pajak diharapkan tetap memiliki rasa nasionalisme yang tinggi sehingga dapat meningkatkan pendapatan asli daerah yang dapat membantu terhadap pemenuhan kesejahteraan masyarakat melalui pembayaran PBB.

Yucedogru menyampaikan bahwa mayoritas respondennya mengatakan bahwa tidak terdapat hubungan antara patriotisme dengan membayar pajak. Mereka menyatakan bahwa jikapun mereka tetap membayar pajak adalah bukan karena jiwa nasionalisme mereka, melainkan agar sistem yang ada tetap berjalan.

Berdasarkan teori atribusi, nasionalisme merupakan penyebab internal yang dapat mempengaruhi persepsi wajib pajak dalam membuat keputusan mengenai perilaku kepatuhan wajib pajak dalam melaksanakan kewajiban perpajakannya. Beberapa indikator nasionalime menurut Iskandar adalah (1) bangga menjadi bangsa dan menjadi bagian dari masyarakatIndonesia; (2) mengakui dan menghargai sepenuhnya keanekaragaman pada diri bangsa Indonesia; (3) bersedia mempertahankan dan memajukan negara serta nama baik bangsa; (4) senantiasa membangun rasa persaudaraan, solidaritas dan kedamaian antar kelompok masyarakat dengan semangat persatuan; (5) menyadari sepenuhnya sebagai bagian dari bangsa lain untuk menciptakan hubungan kerja sama saling menguntungkan; (6) memiliki rasa cinta tanah air Indonesia; dan (7) menempatkan kepentingan bersama di atas kepentingan sendiri dan golongan atau kelompok.

\footnotetext{
${ }^{15}$ Lavoie, R., Digital Commons At Loyola Marymount Patriotism And Taxation: The Tax Compliance Implications Of The Tea Party Movement, 2011, h.45.
} 


\section{Religiusitas dan Nasionalisme}

Islam merupakan agama yang nasionalis.Bagi kaum muslimin, kehadiran paham nasionalisme bersentuhan langsung dengan nilai-nilai Islam yang telah lebih lama berada di tengahtengah mereka. Bagi mereka, nasionalisme harus memperhatikan kepentingan seluruh warga bangsa dengan basis ukhuwah Islamiyah. Nasionalisme yang demikian ini merupakan bagian integral dari konsep "Pemerintahan Madinah" yang dibangun oleh Rasulullah Saw bersama para sahabatnya. Inilah yang disebut nasionalisme Islam.

Beberapa dalil tentang nasionalisme dalam Islam tercermin dalam beberapa ayat dalam Al Qur'an yang menyebut tentang negeri. Rasulullah pun sangat mencintai negerinya, karena apabila suatu negeri tidak makmur, aman, sentosa maka rakyatnya pun tak dapat hidup tenteram di dalamnya.

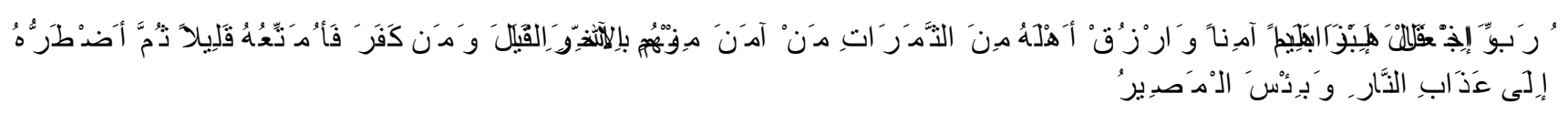

Dan (ingatlah), ketika Ibrahim berdoa: 'Ya Tuhanku, jadikanlah negeri ini negeri yang aman, dan berikanlah rezki kepada penduduknya dari (berbagai macam) buah-buahan, (yaitu penduduknya)yang beriman di antara mereka kepada Allah dan hari kemudian." Allah berfirman: "Dan siapa yang kafir maka Aku beri kesenangan sementara, kemudian Aku memaksanya menjalani siksa neraka dan itulah seburuk-buruk tempat kembali“ (Al Baqarah: 126).

\section{Moral Pajak dan Kepatuhan Pajak}

Moral pajak merupakan motivasi intrinsik wajib pajak untuk mematuhi dan membayar pajak, sehingga sudah selayaknya menjadi fokus utama kebijakan otoritas pajak.16 Ditambah dengan sistem pajak Indonesia yang masih menganut self assesment system untuk diterapkan bagi wajib pajak orang pribadi, yaitu sistem yang memberikan keleluasaan dalam menghitung, melapor, menyetor dan mempertanggungjawabkan kewajiban pajak WPOP kepada otoritas pajak. Sistem self assesment ini rawan sekali dengan kemungkinan adanya kebohongan, kecurangan dan penundaan dalam pelaporan maupun penyetoran, sehingga diperlukan suatu motivasi yang kuat dari masing-masing WP yang berasal dari dalam dirinya sendiri untuk patuh dan taat pada undang-undang perpajakan yang berlaku.

Banyak topik dan faktor yang telah ditelaah dalam penelitian terdahulu mengenai moral pajak ini. Beberapa faktor internal atau yang berhubungan dengan masing-masing individu wajib pajak dan memperngaruhi moral pajak yang telah terungkap di beberapa penelitian terdahulu diantaranya adalah pengetahuan, kesadaran, pendidikan, keluarga, nilai-nilai kepercayaan dan agama (religiusitas), nilai-nilai moral, usia dan gender serta kepercayaan kepada pemerintah. Selain faktor-faktor eksternal yang berupa tarif pajak, sanksi pajak, audit pajak, pelayanan fiskus, korupsi, keadilan dan ketegasan sistem pajak, kemudahan transaksi pelaporan dan pembayaran pajak.

Penelitian ini mengkritisi penelitian Muthia yang mengambil indikator moral pajak berdasarkan kebanggaan nasional, kepercayaan pada pemerintah, kondisi ekonomi, sistem perpajakan dan sanksi pajak. Penulis berpendapat bahwa indikator kondisi ekonomi, sistem perpajakan serta sanksi pajak tidaklah dapat digolongkan sebagai unsur intrinsik. Kebanggaan

${ }^{16}$ Cahyonowati, N, Model Moral Dan Kepatuhan Perpajakan : JAAI, Vol. 15 No, 2011, h.161-177. 
nasional dan kepercayaan pada pemerintah juga penulis anggap bukan merupakan indikator moral pajak melainkan lebih tepat disebut sebagai faktor yang mempengaruhi moral pajak.

Berdasarkan kritisi diatas, penelitian ini mengangkat beberapa indikator dibawah ini untuk menjelaskan moral pajak adalah (1) adanya niat yang baik untuk menaati peraturan perpajakan; (2) percaya bahwa pajak bermanfaat untuk keberlangsungan negara; (3) percaya bahwa sudah merupakan kewajiban seorang warga negara untuk patuh dan taat pada undangundang dan peraturan yang berlaku di negaranya, termasuk dalam hal ini peraturan perpajakan.

Indikator-indikator tersebut diatas diambil dengan pertimbangan bahwa moral pajak menurut penulis merupakan suatu motivasi dalam diri masing-masing pribadi yang percaya bahwa pajak adalah suatu kewajiban warga negara dan dibutuhkan oleh negara untuk melangsungkan pemerintahan dan pembangunan sehingga ada niat untuk melaporkan dan membayarkannya.

\section{Kepatuhan Pajak}

Kepatuhan pajak dapat didefinisikan sebagai tingkat dimana seorang wajib pajak memenuhi atau gagal untuk memenuhi peraturan perpajakan yang berlaku di negaranya. Kepatuhan pajak dapat terjadi secara sukarela maupun secara paksaan. Secara sukarela apabila wajib pajak memiliki motivasi untuk melaporkan dan membayar pajak dengan jujur dan tanpa ada keinginan untuk melakukan kecurangan. Sebaliknya, kepatuhan yang dipaksakan adalah apabila dalam memenuhi kewajiban perpajakannya wajib pajak didasari oleh ketakutan dengan adanya sanksi pajak, pemeriksaan pajak, denda pajak dan hukuman apabila terbukti melakukan kecurangan.

Sedikit berbeda pendekatan yang diambil oleh Nurmantu dalam Cahyonowati dalam menjelaskan kepatuhan. Menurut Nurmantu kepatuhan dibedakan menjadikepatuhan formal dan kepatuhan materiil. Kepatuhan formal adalah apabilawajib pajak memenuhi kewajiban perpajakan sebatas ketentuan formal dalam undang-undang perpajakan, sedangkankepatuhan materiil adalah suatu keadaan di mana WP secara substantif memenuhi semua ketentuan materiil perpajakan yakni sesuai isi dan jiwa undang-undang perpajakan.17

Kepatuhan pajak menurut Internal Revenue Service (IRS) dapat didefinisikan melalui tiga variabel, yaitu (1) kepatuhan penyerahan SPT (filling compliance), (2)kepatuhan pembayaran (payment compliance), dan (3) kepatuhan pelaporan (reporting compliance).

\section{METODE}

Penelitian ini merupakan penelitian kuantitatif yang menggunakan data primer. Sumber data didapatkan dari kuesioner yang disebarkan kepada 238 wajib pajak orang pribadi yang beragama Islam. Pengambilan sample sebanyak 238 responden ini berdasarkan asumsi bahwa sample yang dapat diambil adalah dengan mengalikan antara jumlah indikator dengan 15 . Dalam penelitian ini terdapat 16 indikator, sehingga jumlah perkaliannya menjadi 240. Namun pada saat kuesioner disebar hingga batas waktu yang ditentukan, peneliti hanya berhasil mendapatkan sebanyak 238 kuesioner.

Jumlah variabel laten dalam penelitian ini tidak sampai dengan lima buah (hanya 4 buah) dan setiap variabel laten dijelaskan oleh tiga atau lebih indikator, sehingga jumlah sample sebanyak 100-150 dianggap sudah memadai (Santoso, 2015). Sample dipilih secara acak atau dengan metode random sampling. Analisis data dalam penelitian ini akan dilakukan dengan Structural Equation Modelling (SEM) dan diolah dengan menggunakan program AMOS 21.

${ }^{17}$ Cahyonowati, N., Model Moral Dan Kepatuhan Perpajakan : JAAI, Vol. 15 No, 2011, h. 161-177 
Uji asumsi yang harus dipenuhi dalam pengerjaan model dengan menggunakan SEM adalah uji goodness of fit, normalitas, outliers dan multikolinieritas. Setelah uji asumsi tadi terpenuhi maka langkah selanjutnya adalah dengan melakukan analisa outer model (pengujian validitas dan reliabilitas konstruk), dan inner model (pengujian hubungan struktural). Di bawah ini adalah model pengujian hipotesis yang dibentuk pada penelitian ini.

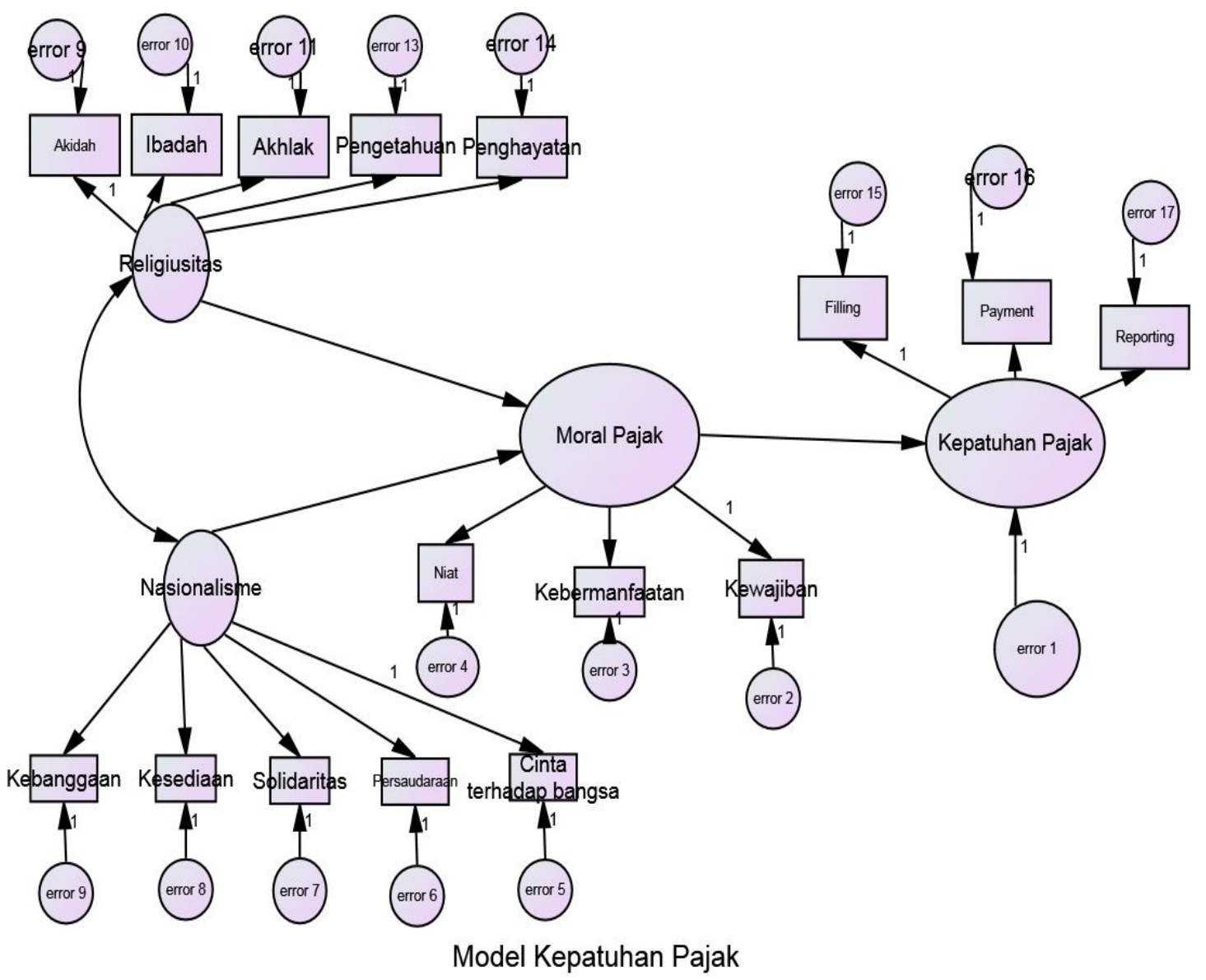

Gambar 1. Model Kepatuhan Pajak

Kuesioner yang dibagikan berisikan pertanyaan masing-masing dua buah untuk menjelaskan setiap indikator yang diberikan. Masing-masing pertanyaan diukur dengan menggunakan skala likert dengan level persetujuan 1 hingga 5, dimana 1 berarti responden berpendapat sangat tidak setuju, sementara 5 berarti responden menyatakan sangat setuju.

\section{HASIL DAN PEMBAHASAN}

\section{Hasil Outer Model}

Pengujian outer model dilakukan dengan melakukan overall model fit test dan convergent and discriminant validity test. Pengujian ini dilakukan untuk memastikan bahwa indikator untuk tiap-tiap konstruk dapat menjelaskan konstruk tersebut dengan tepat. Hasil dari overall model fit test menunjukkan bahwa probablility level terdapat di angka 0,24 yang berarti ada jauh diatas 0.05 atau model dapat dianggap fit. Dengan alat uji lain pun, model masih bisa dianggap fit. Nilai GFI dan AGFI adalah 0.961 dan 0.928, angka tersebut menunjukkan kedekatan dengan 1 yang berarti terdapat indikasi bahwa model dapat dianggapp fit. Selain itu nilai RMSEA juga menunjukkan indikasi yang baik di angka 0.000 .

Sedangkan untuk uji validitas konvergen didapatkan hasil pada tabel di bawah ini. 
Tabel 1. Regression Weights: (Group Number 1 - Default Model)

\begin{tabular}{|c|c|c|c|}
\hline & & Estimate S.E. C.R. & P Label \\
\hline aqidah & $<--$ religiusitas & .983 .2813 .502 & $* * *$ \\
\hline ibadah & $<---$ religiusitas & .826. 265 3.852 & $* * *$ \\
\hline akhlaq & $<---$ religiusitas & 298 3.963 .887$. & *** \\
\hline pengetahuan & $<---$ religiusitas & .845.260 4.014 & $* * *$ \\
\hline penghayatan & $<--$ religiusitas & 340.4161 .475 & .030 \\
\hline kebanggaan & $<---$ nasionalisme & 1.000 & \\
\hline kesediaan & $<---$ nasionalisme & 1.000 & \\
\hline solidaritas & $<---$ nasionalisme & .910 .2303 .472 & $* * *$ \\
\hline persaudaraan & $<---$ nasionalisme & .840. 273 3.988 & $* * *$ \\
\hline cinta & <--- nasionalisme & .742 .1345 .522 & $* * *$ \\
\hline niat & $<---$ moral & .804 .1395 .770 & $* * *$ \\
\hline kebermanfaatan & $<--$ moral & 1.000 & \\
\hline kewajiban & $<---$ moral & 585. 292.499. & .558 \\
\hline filling & <--- kepatuhan & . 809.2714 .280 & *** \\
\hline payment & <--- kepatuhan & .704.1265.290 & $* * *$ \\
\hline reporting & <-- kepatuhan & .804. 1395.770 & $* * *$ \\
\hline
\end{tabular}

Hasil di atas menunjukkan probabilitas dengan tanda *** yang berarti berada di level jauh dari angka 0.05 dimana hal tersebut mengindikasikan bahwa indikator sesuai untuk menjelaskan konstruk yang dimaksud kecuali untuk indikator kewajiban yang berada diatas 0.05 .

\section{Hasil Inner Model}

Tabel 2. Hasil Uji Struktural Model

\begin{tabular}{|lll|rrrrr|}
\hline & & & Estimate & S.E. & C.R. & P & Label \\
\hline Moral & $<--$ & religiusitas & .578 & .106 & 2.437 & .022 & \\
Moral & $<---$ & nasionalisme & .048 & .248 & .196 & .645 & \\
kepatuhan & $<--$ & moral & .412 & .176 & 2.167 & .031 & \\
\hline
\end{tabular}

Berdasarkan tabel di atas dapat diketahui bahwa hasil penelitian ini menunjukkan terdapat relasi yang signifikan antara variabel religiusitas terhadap moral pajak dan moral pajak terhadap kepatuhan pajak, sedangkan nasionalisme rupanya tak signifikan dalam mempengaruhi moral pajak. Sedangkan hubungan antara religiusitas dan nasionalisme menunjukkan korelasi yang tidak kuat, dapat dilihat dari hasil Tabel 3.

Tabel 3. Covariances: (Group number 1 - Default model)

\begin{tabular}{lrrrrrr}
\hline & Estimate & S.E. & C.R. & P & Label \\
\hline religiusitas $<-->$ & nasionalisme & .109 & .022 & .560 & .247 & \\
\hline
\end{tabular}




\begin{tabular}{|c|c|}
\hline & Estimate \\
\hline religiusitas <--> nasionalisme & .224 \\
\hline
\end{tabular}

\section{Religiusitas, Moral Pajak Dan Kepatuhan Pajak}

Variabel religiusitas mempunyai pengaruh yang cukup kuat dengan moral pajak, ditunjukkan dengan angka p (probability) sebesar 0.022 atau berada dibawah 0.05 . Hasil ini sejalan dengan hasil penelitian(Torgler, 2006) yang mengatakan bahwa religiusitas merupakan faktor yang dapat meningkatkan moral pajak.

Hasil penelitian ini juga mendukung hasil yang diperoleh oleh Yucedogru. Pada penelitiannya yang dilakukan secara kualitatif dengan mengadakan interview secara mendalam kepada para responden yang beragama Islam, Yucedogru menemukan bahwa mayoritas responden yang terindikasi religius menganggap bahwa menghindari pajak adalah merupakan suatu dosa. Dari penelitian terdahulu dengan didukung oleh hasil kuantitatif penelitian ini, dapat disimpulkan bahwa tingkat religiusitas seseorang dapat mempengaruhi moral pajaknya hingga memberikannya motivasi untuk mematuhi peraturan perundangan yang berlaku.

Dalam agama Islam, menghindari pajak dengan cara melakukan kecurangan atau kebohongan diyakini merupakan suatu perbuatan yang tidak baik. Selama pajak yang diwajibkan oleh negara diambil secara adil dan memenuhi syaratnya maka sudah merupakan kewajiban warga negara untuk memenuhinya. ${ }^{18}$

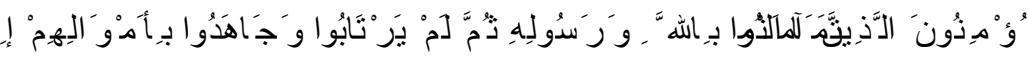



Sesungguhnya orang-orang yang beriman itu hanyalah orang-orang yang percaya (beriman) kepada Allah dan Rasul-Nya, kemudian mereka tidak ragu-ragu dan mereka berjuang (berjihad) dengan harta dan jiwa mereka pada jalan Allah. Mereka itulah orangorang yang benar [Al Hujuraat: 15]

\section{Nasionalisme, Moral Pajak dan Kepatuhan Pajak}

Nilai p pada korelasi antara nasionalisme dan moral pajak menunjukkan angka yang tidak signifikan di angka 0.645, jauh diatas 0.05 dan nilai estimasinya juga menunjukkam ketidakkeratan, 0.048, jauh dibawah 0.5. Hasil penelitian ini bertentangan dengan penelitian yang dilakukan oleh Konrad and Qari dan Purnamasari. Namun lagi-lagi hasil penelitian ini menemukan kata sepaham dengan Yucedogru.

Yucedogru menceritakan bahwa mayoritas respondennya menganggap bahwa nasionalisme dan kepatuhan membayar pajak adalah dua hal yang berbeda. Mereka menekankan bahwa adanya rasa patriotisme tak cukup untuk menegaskan kepatuhan pajak. Adanya kesamaan hasil antara penelitian ini dan penelitian Yucedogru dimungkinkan karena adanya persamaan karakteristik sample yang diambil, yaitu membatasi penelitian dengan mengambil komunitas muslim dan dilaksanakan di negara yang mayoritas penduduknya beragama Islam (Turki dan Indonesia).

Hal ini apabila dikaitkan dengan penelitian milik Purnamasari, maka akan menyentuh isu adanya wajib pajak yang belum percaya terhadap aparat pemerintah maupun sistem hukum yang berlaku di negaranya. Ketidakpercayaan terhadap pemerintah dan sistem hukum negara sedikit banyak mempengaruhi hubungan antara nasionalisme dengan moral pajak. Sudah

18http:// muslim.or.id/ 6283-pajak-dalam-islam.html, diakses 16 November 2016. 
merupakan suatu kepastian, bahwa korupsi dan praktik penghindaran pajak seringkali memiliki seringkali memiliki tingkat persistensi dan korelasi yang tinggi. ${ }^{19}$

Responden membedakan antara rasa cinta tanah air dan kesiapan membelanya kapanpun dibutuhkan dengan kepatuhan menaati pemerintah dan sistem hukum yang dibuat oleh pemerintah karena merasa bahwa pemerintah bukanlah representasi dari negara. Bahkan menurut gerakan tea party movement patriotisme seseorang justru ditunjukkan dengan gerakan anti-tax. Dengan dilakukannya gerakan anti tax, diharapkan pemerintah mau mendengarkan suara dari para demonstran itu. Walau jumlah pengikut gerakan ini sedikit untuk saat ini dan dampaknya pun tidak signifikan, namun apabila pemerintah tidak mengambil langkah untuk menghadapinya maka dikhawatirkan pengikutnya akan semakin banyak dan efeknya pun semakin besar.

\section{Nasionalisme dan Religiusitas}

Hubungan antara variabel eksogen ditelaah juga dalam penelitian ini, dan hasilnya menunjukkan ketidakeratan diantara keduanya, dengan nilai estimasi sebesar 0.224 dan nilai $\mathrm{p}$ sebesar 0.247. Hasil ini mendapatkan pembuktian dari asumsi yang dimiliki oleh Brubaker mengenai adanya pemahaman kritikal bahwa nasionalisme adalah fenomena khas sekular, dan sekulerisme adalah sesuatu yang berlawanan dengan religiusitas. Sekulerisme adalah suatu paham yang memisahkan antara urusan negara dengan agama. ${ }^{20}$

Ketidakeratan hubungan antara nasionalisme dan religiusitas menurut hasil dari penelitian ini berbeda dengan pernyataan yang diusung oleh Capelos and Chrona (2012) yang menyatakan bahwa dua hal ini -nasionalisme dan religiusitas- merupakan dua elemen yang saling mendukung dalam membentuk perilaku seorang warga negara.

Perbedaan hasil ini kembali lagi barangkali dikarenakan adanya unsur ketidakpercayaan kepada pemerintah, karena pada perhitungan statistik deskriptif dari masing-masing indikator, nilai kesediaan lah yang menempati nilai rata-rata terendah, dimana dalam kuesioner, indikator kesediaan tersebut disusun melalui dua pertanyaan, yaitu (1) Anda bersedia untuk memenuhi segala peraturan yang dibuat oleh pemerintah Republik Indonesia; (2) Anda bersedia dan siap untuk memberikan kontribusi nyata bagi bangsa dan negara kapanpun diminta. Hasil dari indikator ini cukup rendah karena setelah dilakukan wawancara dengan lebih mendalam, diketahui bahwa beberapa responden merasa pemerintah belum melindungi rakyatnya dengan sepenuhnya.

\section{Moral Pajak dan Kepatuhan Pajak}

Moral pajak secara signifikan dan cukup erat mempengaruhi kepatuhan pajak dengan tingkat p sebesar 0.031 dan nilai estimasi yang berada di angka 0.412 . Sesuai dengan penelitian Cahyonowati, moral pajak menentukan kepatuhan seseorang dalam mematuhi peraturan perpajakan, walau menurut Cahyonowati kepatuhan yang ada di Indonesia ini masih merupakan kepatuhan yang dipaksakan, bukan kepatuhan sukarela. ${ }^{21}$

Hubungan yang kuat antara moral pajak dan kepatuhan pajak ini sesuai dengan temuan empiris Togler yang mendukung relevansi penggabungan faktor non-ekonomike dalam analisis kepatuhan pajak. Perluasan dari model ekonomi manusia dengan menyertakan faktor

\footnotetext{
${ }^{19 L i t i n a, ~ A ., ~ \& P a l i v o, ~ C o r r u p t i o n ~, ~ T a x ~ E v a s i o n ~ A n d ~ S o c i a l ~ V a l u e s . ~ J o u r n a l ~ O f ~ E c o n o m i c ~ B e h a v i o r ~ A n d ~ O r g a n i z a t i o n, ~ 2015, ~ h . ~ 1-14 . ~}$

${ }^{20}$ Brubaker, R., Religion And Nationalism: Four Approaches Rogers Brubaker Forthcoming In, 2011, h. 1-29.

${ }^{21}$ Cahyonowati, N., Model Moral Dan Kepatuhan Perpajakan : JAAI, Vol. 15 No, 2011, h.161-177.
} 
religiusitas menghasilkan instrumen baru tanpa harus kehilangan robustness-nya. Didalam Togler Iannaccone menunjukkan:22

"Ekonomi agama pada akhirnya akan mengubur dua mitos, bahwa manusia sebagai homo economicus menjadi makhluk tanpa rasa yang tidak mempunyai belas kasih apabila, atau sebaliknya homo religiosus sajayang pra-rasional".

\section{PENUTUP}

Hasil yang dapat disimpulkan dari penelitian ini adalah (1) religiusitas berpengaruh terhadap moral pajak; (2) nasionalisme tidak berpengaruh terhadap moral pajak; (3) moral pajak mempunyai pengaruh terhadap kepatuhan pajak; dan (4) religiusitas dan nasionalime tidak saling mempengaruhi. Berdasarkan simpulan ini dapat ditarik suatu benang merah bahwa masyarakat muslim yang diwakili oleh 238 responden mengganggap bahwa kepatuhan membayar pajak bukan dipengaruhi oleh rasa cinta kepada bangsa melainkan dipengaruhi oleh kepercayaan dalam agama bahwa apabila seseorang melakukan kecurangan atau penghindaran pajak maka hal itu termasuk sebuah dosa, antara religiusitas dan nasionalisme juga merupakan dua hal yang berbeda dan tidak saling mempengaruhi.

Berdasarkan hasil tersebut, dapat disimpulkan bahwa religiusitas masih memainkan peran penting dalam pengambilan keputusan masyarakat muslim ini. Dengan demikian, jika para pembuat kebijakan pajak dapat menyentuh sisi religiusitas masyarakat muslim, yang notabene sebagai mayoritas di negeri ini, diharapkan penerimaan pajak dapat ditingkatkan.

Penelitian ini masih memiliki beberapa kekurangan, di antaranya tidak memasukkan variabel tingkat kepercayaan pada pemerintah. Mengingat dalam beberapa penelitian terdahulu tingkat kepercayaan kepada pemerintah ini memainkan peran penting dalam menjelaskan hubungan antara nasionalisme dan kepatuhan pajak. Selain itu pada saat secara kualitatif dilakukan interview mendalam kepada beberapa orang responden, rupanya tingkat kepercayaan pada pemerintah inilah yang membuat rasa nasionalisme berkurang. Sehingga saran untuk penelitian selanjutnya adalah untuk memasukkan variabel keprcayaan kepada pemerintah sebagai variabel pendukung.

\section{DAFTAR PUSTAKA}

Ali, M. 2012. Factors Affecting Tax Compliant Attitude In Africa : Evidence From Kenya , Tanzania , Uganda And South Africa. N.D, 1-26.

Alm, J., Martinez-Vazquez, J., \&Torgler, B. 2005. Russian Attitudes Toward Paying Taxes - Before, During, And After The Transition.

Alm, J., Martinez-Vazquez, J., \&Wallace, S. 2009. Do Tax Amnesties Work ? The Revenue Effects Of Tax Amnesties During The Transition In The Russian Federation. Economic Analysis And Policy, 39(2) , 235-253.

Anggraeni, M. D. 2011. Pengaruh Pemanfaatan Fasilitas Perpajakan Sunset Policy Terhadap Tingkat Kepatuhan Wajib Pajak.

Basri, Y. M. (N.D.). Pengaruh Gender , Religiusitas Dan Sikap Love Of Money Pada Persepsi Etika Penggelapan Pajak, 45-54.

22Torgler, B., The Importance Of Faith : Tax Morale And Religiosity. Journal Of Economic Behavior \&Organization, 61, 2006, h. 1492. 
Bloomquist, K. M. 2003. Tax Evasion , Income Inequality And Opportunity Costs Of Compliance Office Of Research Paper Presented At The 96 Th Annual Conference. In Paper Presented At The 96th Annual Conference Of The National Tax Association.

Brubaker, R. 2011. Religion And Nationalism: Four Approaches Rogers Brubaker Forthcoming In, 1-29.

Cahyonowati, N. 2011. Model Moral Dan Kepatuhan Perpajakan : JAAI, Vol. 15 No, 161-177.

Chuenjit, P. 2014. The Culture Of Taxation: Definition And Conceptual Approaches For Tax Administration, 22(1), 14-34.

Cyan, M. R., Koumpias, A. M., \&Martinez-Vazquez, J. 2016. The Determinants Of Tax Morale In Pakistan. Journal Of Asian Economics, 47, 23-34.

Gungor, G., \&Izgi, K. 2015. Comparison Of Tax Morale Of Turkish And Spanish Higher Education Students : The Samples Of Sakarya University And The University Of Zaragoza. Procedia Social And Behavioral Sciences, 186, 222-230.

Huslin, D. 2015. Pengaruh Sunset Policy , Tax Amnesty , Dan Sanksi Pajak Terhadap Kepatuhan Wajib Pajak( Studi Empiris Di Kantor Pelayanan Pajak Pratama Jakarta Kembangan), XIX(02), 225-241.

Kok, M., Xin, H., \&Chen, N. H. 2015. Factors Affecting Individual Taxpayers ' Compliance In Malaysian Tax Filing System Abstract: The International Journal Of Business \& Management, 3(9), 339-347.

Kristiaji, B. B., Febriyanto, T., \&Abiyunus, Y. F. 2013. Memahami Ke ( Tidak ) Patuhan Pajak, 614.

Lavoie, R. 2011. Digital Commons At Loyola Marymount Patriotism And Taxation: The Tax Compliance Implications Of The Tea Party Movement, 45.

Litina, A., \&Palivos, T. 2015. Corruption , Tax Evasion And Social Values. Journal Of Economic Behavior And Organization, 1-14.

Modugu, K. P. 2014. Impact Of Tax Audit On Tax Compliance In Nigeria, 5(9), 207-215.

Nasionalisme, R., Islam, D. A. N., Pengaruhnya, S., Kebangkitan, T., Islam, D., Oleh, G., ... Shadily, H. 1983. Relasi Nasionalisme Dan Islam Serta Pengaruhnya Terhadap Kebangkitan Dunia Islam Global Oleh Mugiyono 1, 1-11.

S. N., \&Purnamasari, A. (N.D.). Kepatuhan Wajib Pajak Dalam Membayar PBB-P2, 1-20.

Rahardjo, H. N. 2010. Keterkaitan Sunset Policy Terhadap Program Pascasarjana.

Razak, A. A., \&Adafula, C. J. 2013. Evaluating Taxpayers ' Attitude And Its Influ Ence On Tax 
Compliance Decisions In Tamale , Ghana, 5(September), 48-57.

Richardson, G. 2008. Journal Of International Accounting, Auditing And Taxation The Relationship Between Culture And Tax Evasion Across Countries: Additional Evidence And Extensions, 17, 67-78.

Stella, P. 1991. An Economic Analysis OfTax Amnesties, 46, 383-400.

Syafrida, F. N. (N.D.). Analisis Penerapan Tax Amnesty Di Indonesia Dalam Analysis Ofapplication of Tax Amnesty In Indonesia, 1-2.

Taxpayers, T. S., Benk, S., Budak, T., \&Yüzba, B. 2016. The Impact Of Religiosity On Tax Compliance Among, 1-10.

Torgler, B. 2006. The Importance Of Faith: Tax Morale And Religiosity. Journal Of Economic Behavior \&Organization, 61, 81-109.

Utama, A. 2016. Pengaruh Religiusitas Terhadap Perilaku Kepatuhan Wajib Pajak Orang Pribadi Di Provinsi DKI Jakarta, (2), 1-13.

Weeden, J., \&Kurzban, R. 2013. Evolution And Human Behavior What Predicts Religiosity? A Multinational Analysis Of Reproductive And Cooperative Morals. Evolution And Human Behavior, 8-13.

Http:/ / File.Upi.Edu/ Direktori/ FPIPS/ M_K_D_U/ SAEPUL_ANWAR/Artikel,_Dll/ KOSEP_FITRAH_ DALAM_ISLAM.Pdf., Diunduh Pada 17 November 2016.

Http:// Www.Kemenkeu.Go.Id/ Berita/ Dirjen-Pajak-Tax-Ratio-Indonesia-Masihrendah, Diakses 17 November 2016.

Http:/ / Muslim.Or.Id/ 6283-Pajak-Dalam-Islam.Html, Diakses 16 November 2016.

Http:/ / Www.Pajak.Go.Id, Diakses 12 November 2016. 